\title{
Posterior Dynamic Stabilization for the Treatment of Patients with Lumbar Degenerative Disc Disease: Long-Term Clinical and Radiological Results
}

\author{
Lomber Dejeneratif Disk Hastaliğının Tedavisinde Posterior Dinamik \\ Stabilizasyon Sisteminin Yeri: Uzun Dönem Klinik ve Radyolojik \\ Sonuçlar
}

\author{
Suat CANBAY ${ }^{1}$, Ahmet Levent AYDIN², Elif AKTAS ${ }^{3}$, Serhat Fuat ERTEN ${ }^{1}$, Mehmet BASMACI $^{1}$, \\ Mehdi SASANI ${ }^{4}$, Ali Fahir OZER ${ }^{5}$ \\ ${ }_{1}^{1}$ Dr. Abdurrabman Yurtaslan Oncology Training and Research Hospital, Department of Neurosurgery, Ankara, Turkey \\ ${ }^{2}$ Istanbul Physical Therapy and Rehabilitation Training Hospital, Department of Neurosurgery, Istanbul, Turkey \\ ${ }^{3}$ Dr. Abdurrahman Yurtaslan Oncology Training and Research Hospital, Department of Radiology, Ankara, Turkey \\ ${ }_{4}^{4}$ American Hospital, Department of Neurosurgery, Istanbul, Turkey \\ ${ }^{5}$ Koc University, Faculty of Medicine, Department of Neurosurgery, Istanbul, Turkey
}

Correspondence address: Ali Fahir OZER / E-mail: alifahirozer@gmail.com

\begin{abstract}
AIM: Comparison of long-term preoperative and postoperative clinical and radiological results for patients diagnosed with degenerative disc disease that underwent posterior dynamic stabilization. Lumbar disc degeneration is caused by a variety of factors. Disruptions in the vertebral endplate result in defects in disc nutrition and, thus, disc degeneration. The aims of dynamic stabilization are to unload the disc/facet joints, preserve motion under mechanical load, and restrict abnormal motion in the spinal segment.

MATERIAL and METHODS: Twenty-five patients diagnosed with lumbar degenerative disc disease were enrolled. Totally, 25 vertebral segments were subjected to posterior dynamic stabilization. Patients were clinically evaluated in the preoperative and postoperative periods using the Oswestry Disability Index (ODI) and Visual Analog Scale (VAS). Segmental movement was evaluated radiologically in the late postoperative period by measuring the segmental angles during flexion and extension.

RESULTS: Significant postoperative improvements were observed in the ODI and VAS measurements $(\mathrm{P}<0.01)$. During the long postoperative period (averaging 5 years and 2 months), lumbar lordosis angles, intervertebral space ratio and segmental ratio were measured and compared statistically. Adjacent segment disease developed in two patients. Both patients received L5-S1 discectomy.

CONCLUSION: Good clinical outcomes were observed in the treatment of lumbar degenerative disc disease with a posterior dynamic system. KEYWORDS: Degenerative disc disease, Dynamic stabilization, Lumbar spine, Surgical treatment
\end{abstract}

öz

AMAÇ: Dejeneratif disk hastalığı tanısı almış ve posterior dinamik stabilizasyon sistemi uygulanmış hastaların uzun dönem preoperatif ve postoperatif klinik ve radyolojik sonuçlarının karşılaştırılması. Lomber dejeneratif disk hastalığına birçok etken sebep olur. Bu etkenler sonuç olarak omurga son plaklarında dejenerasyona ve disk dokusunun beslenmesinin bozulmasına yol açar. Dinamik stabilizasyon sistemleri, omurlar arasındaki hareketi korurken, disk ve faset eklemleri üzerindeki aşırı yüklenmeyi azaltır, aynı zamanda da omurga segmentindeki anormal hareketlenmeyi önler.

YÖNTEM ve GEREÇLER: Bu çalışmada, dejeneratif disk hastalığı tanısı konmuş 25 hasta ele alınmıştır. Toplamda 25 omurga segmentine posterior dinamik stabilizasyon uygulanmıştır. Hastalar, preoperatif ve postoperatif dönemde Oswestry Disability Index (ODI) and Vizüel Analog Skala (VAS) ile klinik olarak değerlendirilmiştir. Segmental hareketi değerlendirmek için geç postoperatif dönemde radyolojik olarak fleksiyon ve ekstansiyon grafileri kullanılmıştır.

BULGULAR: Postoperatif dönemde ODI ve VAS ölçümlerinde anlamlı düzelmeler kaydedilmiştir $(P<0,01)$. Ameliyatlardan sonraki uzun dönem takiplerinde (ortalama 5 yıl 2 ay), lomber lordoz açısı, intervertebral aralık oranı ve segmental oran ölçülmüş ve istatiksel olarak değerlendirilmiştir. İki hastada postoperatif dönemde komşu segment hastalığı tespit edilmiş ve bu hastalarda L5-S1 diskektomi uygulanmıştır. SONUÇ: Lomber dejeneratif disk hastalığının cerrahi tedavisinde posterior dinamik stabilizasyon sistemi başarılı sonuçlar vermektedir.

ANAHTAR SÖZCÜKLER: Dejeneratif disk hastalığı, Dinamik stabilizasyon, Lomber omurga cerrahi tedavi 


\section{INTRODUCTION}

Lumbar degenerative disc disease (LDDD) has become a chronic health problem of the population of the modern era. Chronic low back pain is the major outcome of LDDD in the aging or prematurely corroded spine. Generally, low back pain may originate in the vertebral endplates, disc annulus, vertebral periosteum, facet joints, and soft tissues $(1,2,4,6,24)$. The formation of a tear in the annulus fibrosus is the primary cause of discogenic pain and disc degeneration $(2,6,18,24,28)$. The dynamic stabilization system for the spine, also known as the non-fusion pedicle screw stabilization system, was developed to overcome the inherent disadvantages of rigid instrumentation and fusion such as pseudoarthrosis and adjacent segment degeneration $(3,5,13,17)$. Recently, a variety of posterior lumbar dynamic stabilization systems (LPDSSs) have been used as alternatives to fusion for the treatment of degenerative problems in the lumbar spine $(25,26,27,33)$. The aims of dynamic stabilization are to unload the disc/facet joint to preserve motion under mechanical loading and to restrict abnormal motion in the spinal segment $(15,26,29,30)$. In this study, long-term clinical and radiological results for patients diagnosed with lumbar degenerative disc disease who were treated with dynamic stabilization were evaluated both preoperatively (preop) and postoperatively (postop).

\section{MATERIAL and METHODS}

A total of 25 patients diagnosed with lumbar degenerative disc disease were selected for this study. Our indication for dynamic stabilization was only chronically recurring lumbalgia in the case of discogenic pain. The main complaint of these patients was lower back pain, and they did not suffer from leg pain (radicular pain). Patients had increased pain when standing up and walking and decreased pain when lying down and had difficulty in coping with their daily lives due to lower back pain. During physical examinations, the Lasegue test results were negative, and there were no neurological deficits in their lower extremities. All patients underwent medical treatment and physical therapy and rehabilitation (PTR). The duration of the symptoms was 60.2 months on average. All patients were diagnosed with magnetic resonance imaging (MRI), discography (Figure 1). In addition, all patients underwent postop dynamic lumbosacral graphy while standing sideways. Isthmic spondylolisthesis, traumatic vertebral fractures, infections, and instabilities due to tumors were excluded from the study group.

Patient Population in the Lumbar Degenerative Disc Disease Group

Twenty-five patients diagnosed with lumbar degenerative disc disease were enrolled in this study. There were 14 men and 11 women, with a mean age of 39 years (range: 23-70 years). Dynamic stabilization was performed on one lumbar level in each patient.

\section{Evaluation of Quality and Pain Scores}

The patients' quality of life and pain scores were evaluated preoperatively and postoperatively using the Visual Analog
Scale (VAS) and the Oswestry Disability Index (ODI). The preop and postop VAS and ODI values were compared (7).

\section{Radiological Analysis}

Radiological analyses of the patients were focused on the intervertebral space ratio (IVS) and lumbar and segmental lordosis angles. These mean values were compared preoperatively and postoperatively at the 12 th month and late postoperative period.

Each patient was subjected to lateral flexion and extension lumbosacral graphy (dynamic lumbar graphy) postoperatively (in the standing position). The segmental lordotic angle was measured to assess the range of motion in the operated segment. Segmental lordosis of the operative level was measured as the angle between lines drawn from the upper and lower endplates of the vertebrae (Figure 2). Intervertebral space ratio and lumbar lordosis angles were measured and compared preoperatively and postoperatively for each patient (Figure 3).

MRI was performed during the preop and postop periods.

\section{Surgical Procedure}

All operations were performed under general anesthesia

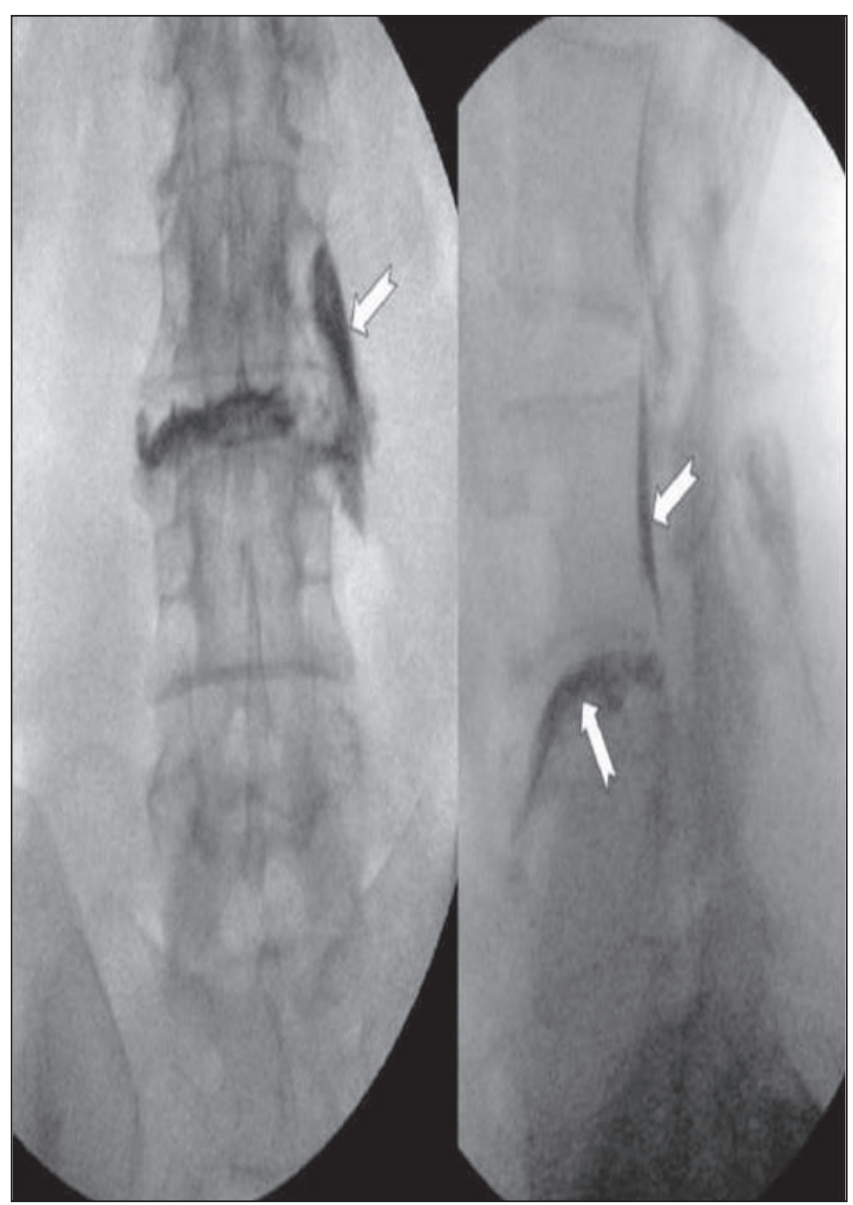

Figure 1: The contrast agent has escaped to the exterior of the nucleus pulposus, as is visible in anterior and lateral discography. 
in the prone position. Two paraspinal skin incisions were made for stabilization, each located $4 \mathrm{~cm}$ laterally from the processus spinalis vertebrae in 6 of the cases and two

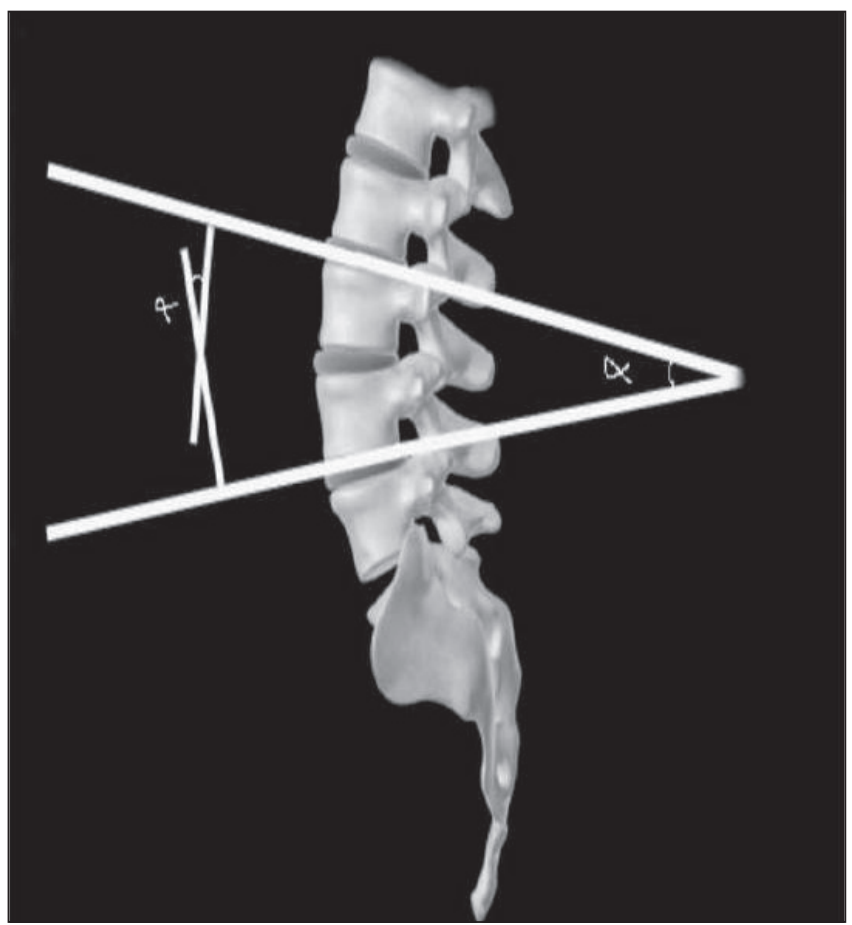

Figure 2: Measurement of the segmental angle.

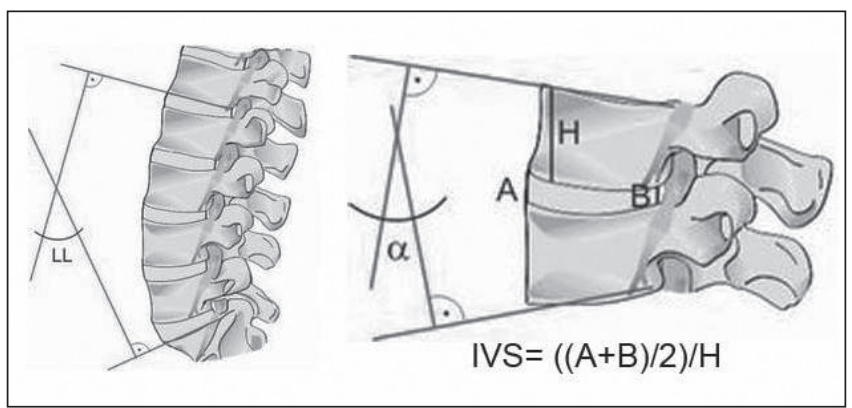

Figure 3: Measurement of segmental lordosis angle (a), lumbar lordosis angle (LL), and intervertebral space (IVS). Abbreviations: $\mathrm{A}, \mathrm{B}, \mathrm{H}$. paramedian fascial incisions were made using one median skin incision in 15 cases (Figure 4). The fascia thoraco-lumbalis was split, and the fingers were used to prepare the muscular system between the multifidus and the longissimus to reveal the transverse processes.

The screw implantation was performed under lateral fluoroscopy control (C-arm). Before the rod was implanted, the correct positioning of the patient was verified by adjusting the degree of spinal lordosis as close to normal physiological alignment as possible. Bilateral rods were connected to the screws, and dynamic stabilization was performed with Cosmic dynamic screw plus a rigid rod in 25 patients [Cosmic dynamic transpedicular screws (Ulrich GmbH \& Co KG)]. (Figure 5).

All of the patients were treated by the same two experienced surgical teams.

\section{STATISTICAL ANALYSIS}

\section{Statistical Methods}

The NCSS (Number Cruncher Statistical System) 2007 and PASS 2008 Statistical Software (Utah, USA) programs were used for the statistical analysis of the results of this study. Descriptive statistical methods (average, standard deviation, median, frequency, ratio) were used for the data evaluation.

The paired samples test was used for the comparison of quantitative data showing a normal distribution of parameters between the 2 groups, and the Friedman test and Wilcoxon Signed Rank were used for the comparison and evaluation of non-normally distributed parameters between the 2 groups as VAS and Oswestry parameters. The significance level was evaluated at $P<0.05$.

The study was performed between 2005 and 2009, at two different centers, namely Koc University American Hospital Istanbul and Dr. Abdurrahman Yurtaslan Oncology Training and Research Hospital, Ankara.

Totally 25 patients were included in the study. $44 \%(n=11)$ were female and $56 \%(n=14)$ were male. The age range of the cases was between 23 and 70 years, mean age was $39.00+$ 11.74 years (Table I, II).

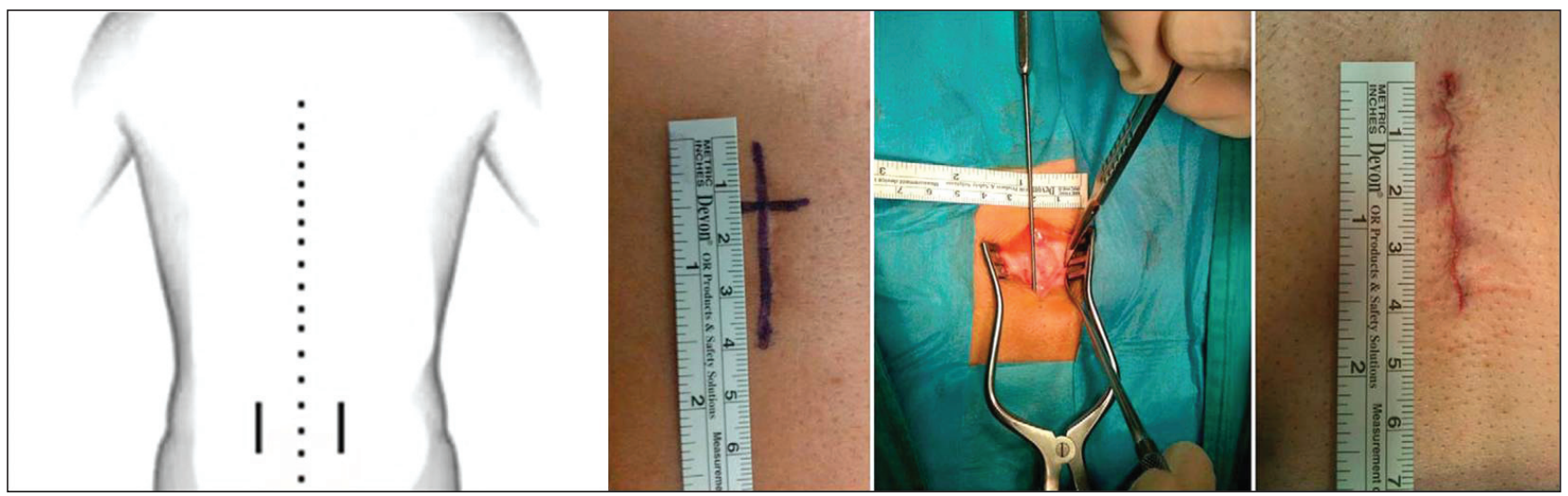

Figure 4: Lumbar bilateral paramedian incision. 
Table I: Patient Demographics

\begin{tabular}{|c|c|c|c|}
\hline & Min-Max & Average $\pm S D$ \\
\hline \multicolumn{2}{|c|}{ Age (years) } & $23-70$ & $39,00 \pm 11,74$ \\
\hline \multirow{2}{*}{\multicolumn{2}{|c|}{ Follow up time(years) }} & $2,00-6,33$ & $3,49 \pm 1,39$ \\
\hline & & $\mathbf{n}$ & $\%$ \\
\hline Gender & $\begin{array}{l}\text { Female } \\
\text { Male }\end{array}$ & $\begin{array}{l}11 \\
14\end{array}$ & $\begin{array}{l}44,0 \\
56,0\end{array}$ \\
\hline
\end{tabular}

The follow-up time of the cases was between 2 and 6.33 years, (mean $3.49 \pm 1.39$ ).

Table II: Evaluation of the Operated Segments

\begin{tabular}{|c|c|c|} 
& $\mathbf{n}$ & $\%$ \\
\hline L4-L5 & 19 & 76,0 \\
\hline L5-S1 & 6 & 24,0 \\
\hline
\end{tabular}

$76 \%$ ( $n=19)$ of the cases were operated for $L 4-5$ segment pathology, and $24 \%$ $(n=6)$ for L5-S1 segment pathology.

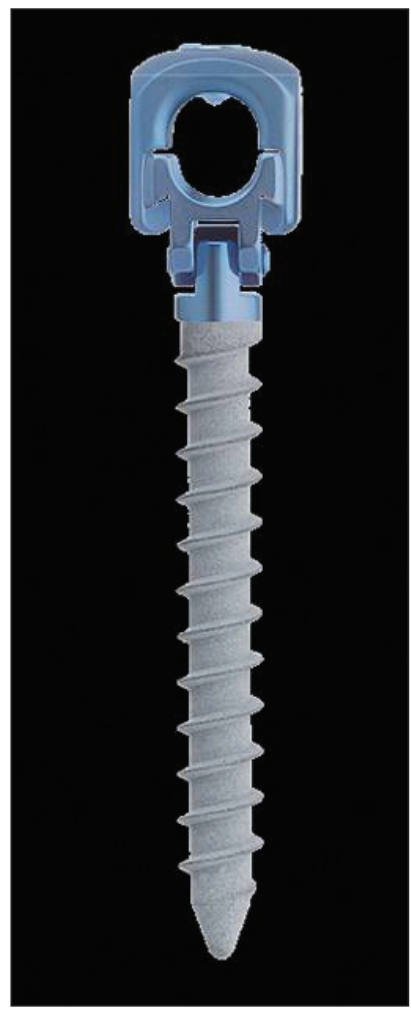

Figure 5: Cosmic dynamic transpedicular screw (Ulrich GmbH \& Co KG, Ulm, Germany). The motion of the Cosmic screw is between the shaft and head of the screw.

A statistically significant difference was discovered between the preoperative and first year postoperative VAS scores of the cases $(p<0.01)$. Dual comparison indicated that this great difference originated from great decline of VAS at the first postoperative year, when compared to preoperative VAS (5.88 unit decrease), and moreover the great decline of VAS in the late postoperative period (6.56 unit decrease). This result was statistically significant $(p<0.01)$. The decrease in VAS score in the late postoperative period when compared with postoperative first year was statistically significant (0.68 unit decrease, $\mathrm{p}<0.01$ ) (Table III).
A statistically significant difference was discovered between the preoperative and first year postoperative OSW scores of the cases $(p<0.01)$. Dual comparison indicated that this great difference originated from 47.20 unit decline of the OSW score according to the preop score, and the 50.64 unit decline in the late period $(p<0.01)$. The decline of the score in the late period by 3.44 units compared with the first postoperative year is also significantly significant $(p<0.01)$ (Table IV).

Difference between preoperative and postoperative LL, segmental lordosis angle and IVS measurements were found to be statistically insignificant ( $p>0.05$ ) (Table V, VI, VII).

\section{RESULTS}

Significant improvements were observed in the ODI and VAS measurements at 12 months after surgery and at the longterm follow-up.

Adjacent segment disease developed in two patients (Patients 1, 3). Approximately two years after dynamic stabilization due to L4-5 degenerative disc disease, patient number 1 underwent discectomy after being diagnosed with disc hernia in the L5-S1 extrusion. Similarly, approximately 1.5 years after dynamic stabilization due to L4-5 degenerative disc disease, patient number 3 underwent discectomy after being diagnosed with a disc hernia in the L5-S1 extrusion. However, both patients had black L5-S1 discs with Pfirrmann Grade 3 degeneration prior to dynamic stabilization.

Movement was still observed in all patients who were subjected to dynamic stabilization based on measurements of the segmental lordotic angle, as visualized in direct lumbosacral graphies during flexion and extension in the long-term postop period (Figure 6).

Segments with segmental angle differences of 0 and 1 were classified as immobile. The screw was broken during the postop period in one patient (Patient number 4). In this patient the right $L 5$ pedicle screw was found to be broken during the third postop year. However, there was no deterioration of clinical manifestations in this patient.

There were no other complications, nor mortality. No infection, chronic inflammation, or fibrosis was observed during the long-term follow-up period.

The mean duration of surgery was 80 minutes (range: 70-90 minutes). The mean estimated blood loss was $175 \mathrm{ml}$ (range 
Table III: Evaluation of the VAS Measurements

\begin{tabular}{|c|c|c|c|}
\hline \multirow{2}{*}{ Follow up time } & \multicolumn{2}{|c|}{ VAS } & \multirow{2}{*}{${ }^{+} \mathbf{p}$} \\
\hline & Median \pm SD & Median & \\
\hline Preop & $7,60 \pm 1,29$ & 8,00 & \multirow{3}{*}{$0,001 * *$} \\
\hline First year & $1,72 \pm 0,89$ & 2,00 & \\
\hline \multirow[t]{2}{*}{ Late period } & $1,04 \pm 0,89$ & 1,00 & \\
\hline & \multicolumn{2}{|c|}{${ }^{++} \boldsymbol{p}$} & \\
\hline Preop-First year & \multicolumn{2}{|c|}{$0,001 * *$} & \\
\hline Preop-Late period & \multicolumn{2}{|c|}{$0,001 *$} & \\
\hline First year-Late period & \multicolumn{2}{|c|}{$0,001 * *$} & \\
\hline
\end{tabular}

${ }^{+}$Friedman Test, ${ }^{++}$Wilcoxon Signed Ranks Test, ${ }^{* *} p<0,01$.

VAS DIFFERENCE DURING FOLLOW UP

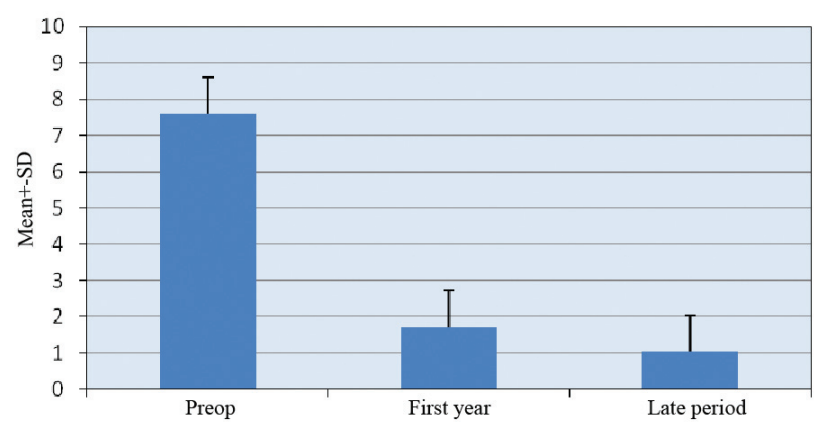

Table IV: Evaluation of the Oswestry Disability Index

\begin{tabular}{|c|c|c|c|}
\hline & \multicolumn{2}{|c|}{ OSWESTRY } & \multirow{2}{*}{${ }^{+} \boldsymbol{p}$} \\
\hline & Med \pm SD & Median & \\
\hline Preop & $57,36 \pm 16,27$ & 58,00 & \multirow{3}{*}{$0,001 * *$} \\
\hline First year & $10,16 \pm 4,70$ & 8,00 & \\
\hline \multirow[t]{2}{*}{ Late period } & $6,72 \pm 3,00$ & 6,00 & \\
\hline & \multicolumn{2}{|c|}{${ }^{++} \boldsymbol{p}$} & \\
\hline Preop-First year & \multicolumn{2}{|c|}{$0,001 * *$} & \\
\hline Preop-Late period & \multicolumn{2}{|c|}{$0,001 * *$} & \\
\hline First year-Late period & \multicolumn{2}{|c|}{$0,001 * *$} & \\
\hline
\end{tabular}

${ }^{+}$Friedman Test, ${ }^{++}$Wilcoxon Signed Ranks Test, ${ }^{* *} p<0,01$.

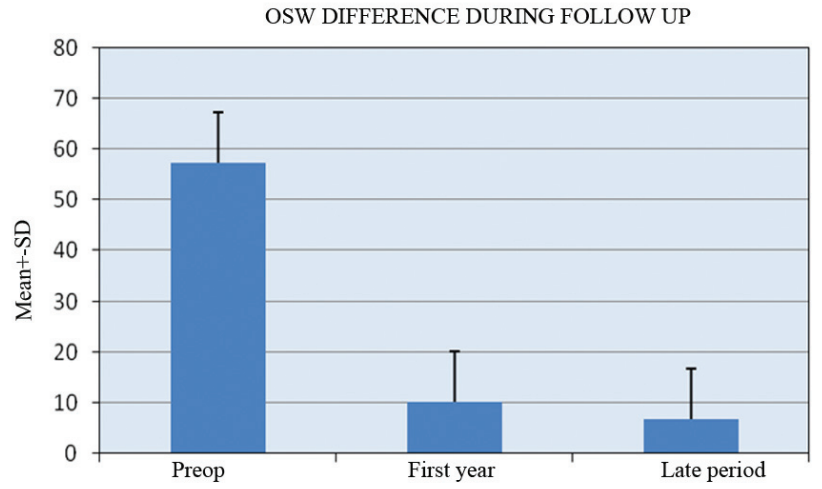


Table V: Evaluation of LL Measurements

\begin{tabular}{|l|c|c|c|}
\multirow{2}{*}{ Preop } & \multicolumn{2}{|c|}{ LL } & P \\
\cline { 2 - 4 } & Med \pm SD & Median & $\mathbf{0 . 6 2 2}$ \\
Postop & $39.88 \pm 11.25$ & 43.00 & 38.00 \\
\end{tabular}

Paired Samples Test

Table VI: Evaluation of the IVS Measurements

\begin{tabular}{|c|c|c|c|}
\hline & \multicolumn{2}{|c|}{ IVS } & \multirow{2}{*}{$\mathbf{p}$} \\
\hline & Med \pm SD & Median & \\
\hline Preop & $0.25 \pm 0.07$ & 0.28 & \multirow{2}{*}{0.964} \\
\hline Postop & $0.26 \pm 0.07$ & 0.26 & \\
\hline
\end{tabular}

Paired Samples Test

Table VII: Evaluation of the Alpha (Segmental ILordosis) Angle

\begin{tabular}{|l|c|c|c|}
\multirow{2}{*}{} & \multicolumn{2}{|c|}{ Alpha angle } & P \\
\cline { 2 - 3 } & Ort \pm SD & Median & \multirow{2}{*}{$\mathbf{0 . 7 7 9}$} \\
Preop & $15.44 \pm 8.06$ & 12.0 & 16.0 \\
\hline
\end{tabular}

Paired Samples Test

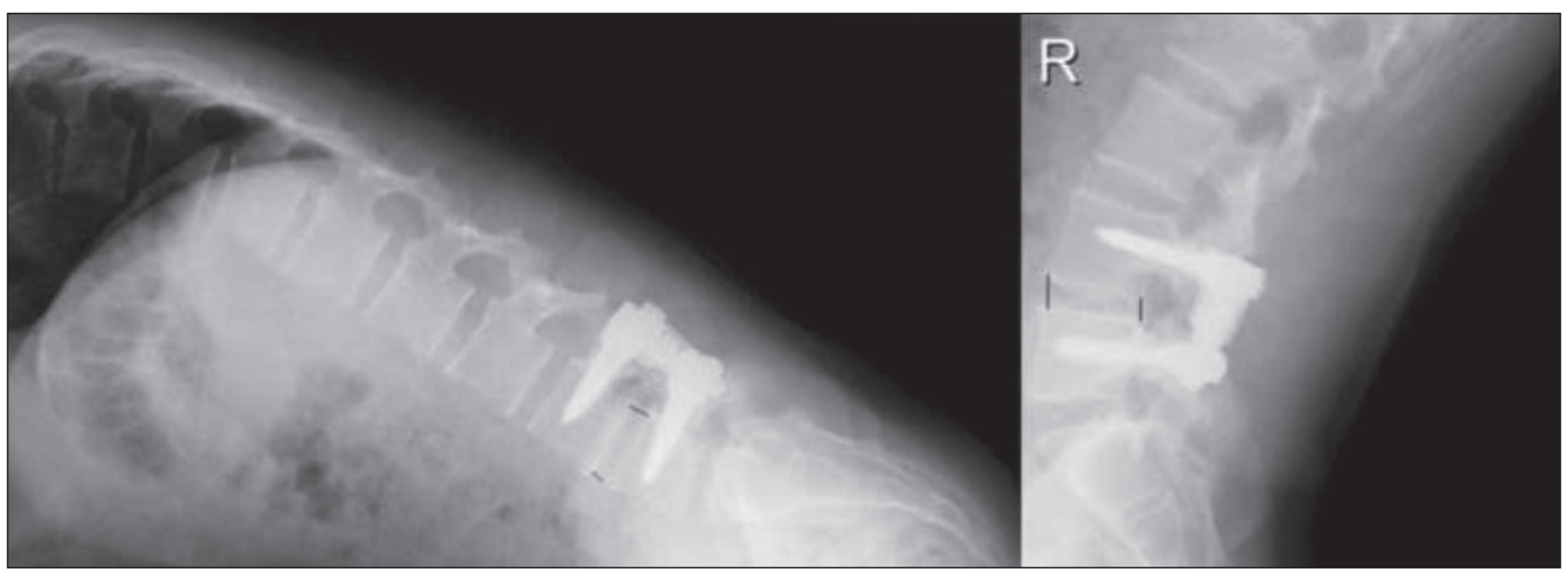

Figure 6: In the lumbar functional graphy of the late postop period, segmental movement is still observed during flexion and extension.

50-300 ml). The mean hospital stay duration was five days (range: three to seven days).

Considerable clinical improvements were observed in our group of patients. There was a significant decrease in the VAS and ODI scores during the postop period compared with the preop period. In one patient, screw breakage occurred at postop year 3. Nevertheless, during the subsequent followup period, clinical improvements continued in all patients, and the late postop period VAS and ODI scores were relatively good. This situation led us to postulate that the segment undergoing dynamic stabilization improved with time; in fact, the disappearance of annulus fibrosus tears in the postop late period MRI findings is an indicator of these improvements. All patients were shown to retain segmental movement during the late postop period.

\section{DISCUSSION}

Lumbar disc degeneration is caused by a variety of factors. Disruptions in the vertebral endplate result in defects in disc nutrition and thus disc degeneration $(6,20,23)$. Various factors such as aging, apoptosis, collagen matrix disorders, neovascularization, loads carried by the disc, and abnormal proteoglycan level accelerate the process of disc degeneration $(2,4,6,24,28)$. 
Since its first identification in 1934 by Mixter and Barr, disc rupture accompanied by monoradiculopathies has been recognized as a pathology requiring surgery. However, patients presenting with lower back pain but with minimal or no radicular pain were not accepted as suitable for surgery.

With more recent developments, the anatomic, physiological, and biochemical properties of intervertebral disc tissue causing pain have become much better understood $(1,8,11,33)$.

Our understanding of the symptoms of discogenic pain has deepened with the increased resolution available in MRI, the development of new techniques in lumbar disc surgery, the emergence of new concepts regarding the ability to use bone morphogenetic proteins, and detailed research on the results of lumbosacral fusion $(1,2,4,7,15-17,20,22,23,25-27,29,30,33)$.

Discogenic pain syndrome is mainly an adult disease, and its cardinal symptom is low back pain. Low back pain is usually described as a midline or belt-like aching, deep pain, radiating to the buttocks or upper thighs. It is a mechanical pain worsening with motion, decreasing when in supine position.

Even if it appears at first to be a diffuse lower back pain based on patient description, when the patient is questioned in detail and asked to point to the location where the maximal pain is felt, pain localization in $80 \%$ of the cases is consistent with the pathology identified by MRI imaging $(13,15,18,28,29)$. This observation may be related to the segmental innervation of the annulus, which is the most pain-sensitive region of the disc. Pain is described mechanically, and it increases when sitting, standing up, pushing, pulling, bending down, or turning around and decreases when lying down. Lower back pain can spread to the sacroiliac region, the hips, upper back, or the legs but does not usually reach further down.
Sometimes, the pain can spread to the groin or upper front leg. The pain begins slowly and insidiously $(18,20,22,28)$.

The major cause of lumbosacral degenerative disc disease pathogenesis is repetitive or continuous axial loading. Among other causative factors are morbid obesity, genetic factors, occupation, intense and vigorous athletic activities (such as weight-lifting and gymnastics), and smoking $(2,26,23)$. There are a variety of MRI findings that are indicative of degenerative disc disease. However, patients should always be examined with clinical findings in mind, as it is impossible to trust MRI alone in distinguishing between symptomatic and incidental syndromes. In MRI images, T2-weighted sections characteristically show decreased signal intensity in the nucleus pulposus when compared with the adjacent discs. The nucleus pulposus becomes disordered at the edges, and disc height decreases. A dense, point-like signal intensity on the posterior annulus is a sign of annular tears (Figure 7AD). Cortical endplate and bone marrow undergo a three-step change, as described by Modic. Chronic disc disease results in dense sclerosis of the vertebral endplates and adjacent vertebrae corpuses (Type III change). The period between Type I and Type III changes is usually a few years $(2,8,22,28)$.

Reduced intervertebral distance, which is the source of discogenic pain, appears as a black disc in the sagittal T2 $\mathrm{MRI}$ image. The advantages of MRI in this diagnosis are now unequivocally accepted. However, the identification of which disc is the source of pain remains a problem in cases with more than one degenerative disc $(2,8,22,28)$. Therefore, discography represents a good secondary diagnostic method, as it is a dynamic diagnostic method involving the initiation of pain in relation to the disc distance and providing information on the annulus-nucleus structure. Although changes in disc structure can be radiologically visualized using noninvasive
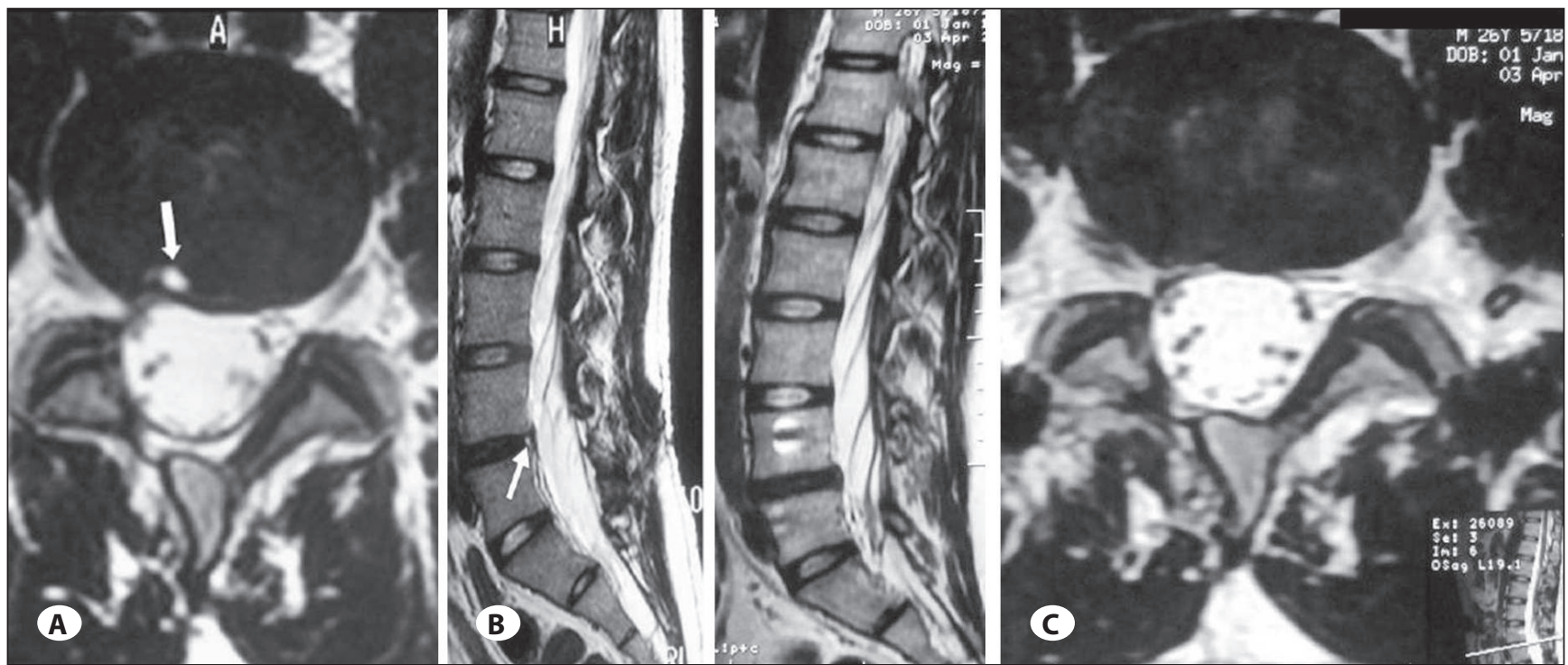

Figure 7: (A) Preoperative axial and (B) sagittal T2-weighted MRI showing the annulus fibrosus tear (high-intensity zone); (C) late postoperative period sagittal and (D) axial T2 MRI images showing healing of the annulus fibrosus tear. 
MRI, the level of symptomatic disc distance can be described by discography, a partially invasive method. Discography allows for the diagnosis of the acute and chronic degeneration of disc structures (such as annulus tears and posterior longitudinal ligament tears) by increasing intradiscal pressure and provoking pain $(2,20,22,26)$.

A conservative first approach is preferred in the treatment of lumbar degenerative disc disease. Exercise programs, physical therapy, epidural injections, a corset if the patient is active, nonsteroidal anti-inflammatory drugs, muscle relaxants, and short-acting narcotic agents can be administered. Patient lifestyle changes should also be implemented.

Surgery should be considered if three to six months of treatment does not produce the desired response $(20,28,29)$. Corrective spinal surgery aims at restoring these pathological processes to as physiological a state as possible. Traditionally, stabilization of the lumbar spine was accomplished by fusion. Fusion surgery of the spine is accomplished by stimulating bone to grow between two or more adjacent spinal segments, thus preventing future motion. To allow for continued mobility at the level that the patient is accustomed to in daily life, the load from immobilized segment angles is distributed to the other segments $(2,11,13,16)$. This in turn results in accelerated degeneration, especially in the adjacent vertebrae, as shown by several studies. During the long-term follow-up period, the occurrence of further degeneration and instability as a result of increased mobility in the segments adjacent to fused spinal segments is an undesirable outcome. As a result, stabilization systems have become more physiological overtime $(7,11,15$, $16,18,20,22,23,28,32$ ).

Dynamic stabilization is the modern alternative to fusion. The instrumentation used in dynamic stabilization is designed to control the amount of motion between adjacent vertebrae, but it does not completely eliminate this movement. Posterior dynamic stabilization is an ideal technique for providing stabilization in cases of chronic instability $(4,7,11,15,16,18,20$, $22,23,29,30)$. The goals of the dynamic stabilization procedure are to control the neutral posture of the segment, control sagittal plane bending of the treated vertebra, unload the intervertebral disc at the treated level, and modify the distribution of loads within the segment, in particular within the intervertebral disc. Unloading the disc, therefore, may create a favorable environment for disc rehydration, self-repair, or possibly regeneration due to the presence of stem cells or bone morphogenetic proteins $(13,15,18,25,27,29,30,33)$.

Graf posterior artificial ligament system was the first used posterior dynamic stabilisation system (12). This system was designed to diminish lumbar facet movements placed under compression forces. This system limits flexion movements and eliminates abnormal rotational motions that might be the origin of chronic low back pain. Graf's system is thought to induce a sharing of the axial load between the painful disc and posterior structures, by providing a posterior tension $(9,12,24)$. However, 2 -year follow-up results using this method were unsatisfactory (14). The poor outcomes were probably related to laxity development in the artificial ligaments and compression forces lead to pain because of root irritation due to foraminal narrowing.

To overcome the disadvantages of the Graf ligament system, The Dynesys Stabilization System (DSS) (Zimmer Spine Inc. Warshow, IN) was developed. This system was thought to overcome risks of foraminal stenosis and annular protrusion of Graf system, and for this purpose, the system used a spacer on the posterior tension band. Biomechanical data from these studies showed that posterior tension band application decreases resistance at the anterior annulus $(1,18)$. Several clinical reports support the positive role of DSS in the treatment of DDD $(3,30,32)$, whereas some other studies showed no benefit of the system for these patients. The most important argument is the system forced flatback deformity particularly when it is applied in multisegment instability $(4,13)$.

Considering the unsatisfactory effects of these dynamic systems, in 1999 Strempel constructed a dynamic screw with a hinge placed between the head and body of the screw (Cosmic, Ulrich AG, Germany). Hinged and calcium phosphatecoated screws allow for a free anterior column with limited flexion and extension capability during stabilization. They share the axial load with the posterior column via a rigid rod [43]. This system provides sufficient stabilization with less stress shielding and greater ROM compared to standard rigid systems.

These systems are suitable for the treatment of instability in each of the three columns and can also be used prophylactically in cases that can develop instability or in the treatment of instability as a result of painful black disc, degenerative spondylolisthesis, recurrent disc herniation, and lumbar canal stenosis treatment $(11,16,20,23,26,29,32)$. It has low complication risks, and its revision is easy. Because the screw heads remain mobile with this procedure, they adapt to the physiological movements of the spine. As a result, complications such as screw pull-out or screw breakage are extremely rare. Posterior dynamic stabilization accomplishes the distribution of a mobile load by dividing it.

Other important advantages of the technique are the following: the surgical intervention can be performed with bilateral paramedian incisions without retracting the paravertebral muscles, thus preventing their possible atrophy during the postop period; the surgery is brief; and the surgery involves less bleeding than fusion surgery.

Posterior dynamic screw stabilization system is free of the above-mentioned limitations and eliminates the risks associated with anterior approach.

Dynamic systems share the load between the anterior and posterior spinal columns. The dynamic posterior stabilization technique (with hinge screw) offers load sharing and load bearing features, while preserving physiological motion. They don't permit abnormal translational movement. Thus, they can unload the disc and also prevent instability. This helps 
to eliminate the pain originating from either degenerative disc disease (discogenic pain) and/or segmental instability $(10,21,31)$.

\section{CONCLUSION}

Based on our results, posterior dynamic transpedincular screw stabilization system is a good choice for patients diagnosed with lumbar degenerative disc disease and complaints of pain for a long period (one year or longer) who are not improving despite medical treatment and physical therapy and rehabilitation. Our results show a satisfactory surgical method in the treatment of DDD. Posterior dynamic screw implantation technique is significantly minimally invasive compared to other dynamic implantation and traditional fusion surgical techniques and an important alternative to fusion in patients with degenerative disc disease. A larger series study, with longer follow-up periods and with control groups, is needed to determine the success and safety of posterior dynamic stabilization in the surgical treatment of degenerative disc disease.

Considerable clinical improvements were observed in our group of patients. There was a significant decrease in the VAS and ODI scores during the postop period compared with the preop period. In one patient, screw breakage occurred at postop third year. Nevertheless, during the subsequent follow-up period, clinical improvements continued in all patients, and the late postop period VAS and ODI scores were relatively good. This situation led us to postulate that the segments undergoing dynamic stabilization improved by time; in fact, the disappearance of annulus fibrosus tears in the postop late period MRI findings is an evidence of the improvement. All patients were shown to retain segmental movement during the late postop period.

\section{REFERENCES}

1. Aylott C, McKinlay KJ, Freeman BJC, McNally DS: The Dynamic Neutralization System for the Spine (Dynesys): Acute biomechanical effects on the lumbar spine. Journal of Bone and Joint Surgery (Br) 87(1):39, 2005

2. Bono $C M$, Kadaba M, Vaccaro AR: Posterior pedicle fixationbased dynamic stabilization devices for the treatment of degenerative diseases of the lumbar spine. J Spinal Disord Tech 22:376-383, 2009

3. Bordes-Monmeneu M, Bordes-Garcia V, Rodrigo-Baeza F, Saez D: System of dynamic neutralization in the lumbar spine: Experience on 94 cases. Neurocirugia (Astur) 16:499-506, 2005

4. Bothmann M, Kast E, Boldt GJ, Oberle J: Dynesys fixation for lumbar spine degeneration.Neurosurg Rev 31:189-196, 2007

5. Bozkuş H, Senoglu M, Baek S, Sawa AG, Ozer AF, Sonntag VK, Crawford NR: Dynamic lumbar pedicle screw-rod stabilization: In vitro biomechanical comparison with standard rigid pedicle screw-rod stabilization. J Neurosurg Spine 12:183189, 2010

6. Cakir B, Richter M, Huch K, Puhl W, Schmidt R: Dynamic stabilization of the lumbar spine. Orthopedics 29:716-722, 2006
7. Fairbank JCT, Pynsent PB:The oswestry disability index. Spine 25(22): 2940-2952, 2000

8. Fayyazi AH, Ordway NR, Park SA, Fredrickson BE, Yonemura K, Yuan HA: Radiostereometric analysis of postoperative motion after application of dynesys dynamic posterior stabilization system for treatment of degenerative spondylolisthesis. J Spinal Disord Tech 23:236-241, 2010

9. Fernand R, Fox DE: Evaluation of lumbar loerdosis. A prospective and retrospective study. Spine 10:799-803, 1985

10. Freudiger S, DuboisG, Lorrain M: Dynamic neutralization of the lumbar spine confirmed on a new lumbar spine simulator in vitro. Arch Orthop Trauma Surg 119:127-132, 1999

11. Gédet P, Haschtmann D, Thistlethwaite PA, Ferguson SJ: Comparative biomechanical investigation of a modular dynamic lumbar stabilization system and the Dynesys system. Eur Spine J 18:1504-1511, 2009

12. Graf H: Lumbar instability; surgical treatment without fusion. Rachis 412:123-137, 1992

13. Grob D, Benini A, Junge A, Mannion AF: Clinical experience with the Dynesis semirigid fixation system for the lumbar spine. Surgical and Patient-oriented outcome in 50 cases after an average of 2 years. Spine 30:324-331, 2005

14. Hadlow SV, Fagan AB, Hillier TM, Fraser RD: The Graf ligamentoplasty procedure. Comparison with posterolateral fusion in the management of low back pain. Spine 23: 1172-1179, 1998

15. Heary RF: Dynamic stabilization. Neurosurg Focus 28(6):E1, 2010

16. Highsmith JM, Tumialan LM, Rodts GE Jr: Flexible rods and the case for dynamic stabilization. Neurosurg Focus 22:E11, 2007

17. Mandigo CE, Sampath P, Kaiser MG: Posterior dynamic stabilization of the lumbar spine: Pedicle based stabilization with the AccuFlex rod system. Neurosurg Focus 22:E9, 2007

18. Niosi CA, Zhu QA, Wilson DC, Keynan O, Wilson DR, Oxland TR: Biomechanical characterization of 3-dimensional kinematic behaviour of the Dynesys dynamic stabilization system; an in vitro study. Eur Spine J 15:913-922, 2006

19. Niosi CA, Oxland TR: Degenerative mechanics of the lumbar spine. Spine J 4:202-208, 2004

20. Nockels RP: Dynamic stabilization in the surgical management of painful lumbar spinal disorders. Spine 30:68-72, 2005

21. OktenogluT, Ozer AF, Sasani M, KanerT, Canbulat N, Ercelen O, Sarioglu AC: Posterior Dynamic Stabilization in the treatment of lumbar degenerative disc disease: 2-year follow-up. Minim Invas Neurosurg 53:112-116, 2010

22. Pfirrmann CW, Metzdorf A, Zanetti M, Hodler J, Boos N: Magnetic resonance classification of lumbar intervertebral disc degeneration. Spine 26:1873-1878, 2001

23. Putzier M, Schneider SV, Funk JF, Tohtz SW, Perka C: The surgical treatment of the lumbar disc prolapse: Nucleotomy with additional transpedicular dynamic stabilization versus nucleotomy alone. Spine 30:109-114, 2005

24. Schmoelz W, Huber JF, Nydegger T, Dipl-Ing, Claes L, Wilke HJ: Dynamic stabilization of the lumbar spine andits effects on adjacent segments: An in vitro experiment. J Spinal Disord Tech 16:418-423, 2003 
25. Schmoelz W, Onder U, Martin A, von Strempel A: Non-fusion instrumentation of the lumbar spine with a hinged pedicle screw rod system: An in vitro experiment. Eur Spine J 18: 1478-1485, 2009

26. Schnake KJ, Schaeren S, Jeanneret B: Dynamic stabilization in addition decompression for lumbar spinal stenosis with degenerative spondylolisthesis. Spine 31:442-449, 2006

27. Schwarzenbach O, Berlemann U, Stoll TM, Dubois G: Posterior dynamic stabilization systems: Dynesys. Orthop Clin North Am 36:363-372, 2005

28. Sengupta DK: Dynamic stabilization devices in the treatment of low back pain. Neurol India 53:466-474, 2005

29. Sengupta DK: Point of view: Dynamic stabilization in addition to decompression for lumbar spinal stenosis with degenerative spondylolisthesis. Spine 31:450, 2006
30. Stoll TM, Dubois G, Schwarzenbach O: The dynamic neutralization system for the spine: A multicenter study of a Novel Non-Fusion System. Eur Spine Journal 11:170-178, 2002

31. Strempel AV, Moosmann D, Stoss C, Martin A: Stabilization of the degenerated lumbar spine in the nonfusion technique with cosmic posterior dynamic system. WSJ 1: 40- 47, 2006

32. Welch WC, Cheng BC, Awad TE, Davis R, Maxwell JH, Delamarter R, Wingate JK, Sherman J, Macenski MM: Clinical outcomes of the Dynesys dynamic neutralization system: 1-year preliminary results. Neurosurg Focus 22:E8, 2007

33. Xu H-Z, Wang X-Y, Chi Y-L, Zhu QA, Lin Y, Huang QS, Dai LY: Biomechanical evaluation of a dynamic pedicle screw fixation device. Clin Biomech 21: 330-336, 2006 